\title{
Application of Membrane Filtration Technique in Preparation of Protein- Rich Feed from Spent Tea
}

\author{
G.A.A. R. Perera ${ }^{1, a,{ }^{*}}$, A.M.T. Amarakoon ${ }^{1, b}$, D.C.K. Illeperuma ${ }^{2}$ and P.K.P. Muthukumarana ${ }^{1}$
}

\section{ABSTRACT}

Spent tea, the main by-product of instant tea manufacture contains $20-30 \%$ crude protein. Though the spent tea is a suitable source of protein for animals, only about $20 \%$ of its protein is bioavailable for them when it is given as a feed in untreated form. Conventional protein isolation procedures are expensive, lengthy and result in protein with reduced nutritive value. Applicability of the membrane filtration technique in preparing a protein-rich feed from the alkali extract of spent tea was investigated. A suitable membrane for filtration was identified and operating parameters were optimized. Dried alkali extract and the concentrates obtained by dia-filtration of the alkali extract were analyzed for nutritionally important constituents. Membrane with molecular weight cut-off of

${ }^{1}$ Biochemistry Division Tea Research Institute of Sri Lanka, Talawakelle 22100, Sri Lanka.

${ }^{2}$ Department of Food Science and Technology Faculty of Agriculture University of Peradeniya, Peradeniya 20400, Sri Lanka.

aPresent address: Department of Export Agriculture, Faculty of Animal Science and Export Agriculture, Uva Wellassa University, Passara Road, Badulla 90000, Sri Lanka

${ }^{b}$ Present address: Department of Chemistry, Faculty of Science, University of Kelaniya, Kelaniya 11600, Sri Lanka

*gaaranjith07@gmail.com

https://orcid.org/0000-0002-0079-247X

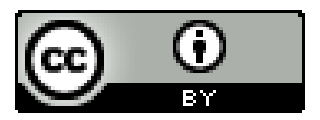

This article is published under the terms of the Creative Commons Attribution 4.0 International License. which permits unrestricted use, distribution and reproduction in any medium provided the original author and source are credited.
100,000 Da and operating temperature of 30 ${ }^{\circ} \mathrm{C}$ and inlet and outlet pressures of 4.6 and 3 bars respectively, were found to be the most suitable for preparing the feed. The dried alkali extract contained $17.5 \%$ protein, $\mathbf{1 2 . 2 \%}$ polyphenols, $2.8 \%$ caffeine and $18.1 \%$ total ash. The dried feed prepared by membrane filtration of alkali extract followed by two consecutive diafiltrations, contained higher level of protein $(24.2 \%)$, low level of polyphenol $(7 \%)$, caffeine $(0.9 \%)$ and total ash $(12.3 \%)$. Further, this feed contained all essential amino acids except threonine.

Keywords: Membrane filtration, Polyphenol, Protein-rich feed, Spent tea

\section{INTRODUCTION}

Tea which is consumed as a beverage after brewing is processed from the young shoot of tea plant (Camellia sinensis (L.) O.Kuntze). Polyphenols which account for 20 to $30 \%(\mathrm{w} / \mathrm{w})$ are the most abundant group of chemicals present in tea leaf (Balentine et al. 1998). Tea leaf contains 2 to $5 \%(\mathrm{w} / \mathrm{w})$ caffeine depending on the cultivar (Harbowy and Balentine, 1997). While caffeine is the most well known nitrogenous compound of tea, other nitrogenous compounds like proteins/peptides and amino acids are also present in tea leaf. The contribution of amino acids $(6 \%)$ and protein $(6 \%)(\mathrm{w} / \mathrm{w})$ to the extractable solid is about $12 \%(\mathrm{w} / \mathrm{w})$ (Harbowy and Balentine, 1997). Theanine ( $\mathrm{N}$ - ethyl-L-glutamine), the major amino acid present in tea usually accounts for 
more than $50 \%$ of the free amino acid fraction of tea leaf (Balentine et al. 1998; Harbowy and Balentine, 1997).

The rejected fractions, during cleaning, sorting and grading in black tea manufacture, are pooled to form a portion collectively called "refuse tea" or "waste tea". The tea leaves left after brewing is called spent tea or infused tea. Spent tea is the main by-product of the instant tea manufacturing process.

Refuse tea and spent tea contain 20 to $30 \% \quad$ crude protein (Ananthasubramaniam and Menachery, 1977; Wickremasinghe, 1978). Spent tea leaf is a suitable source of protein for young calves (6-8 months old) (Jayasuriya et al. 1978), milking cows (Jayasuriya et al. 1982) and chicks (1-5 weeks old) (Kadirvel, 1980) at 20\%, 8\% and 5\% level in the total dry matter of the diet, respectively. However, due to the presence of high level of lignin in the cell wall, only about $20 \%$ of protein present in untreated spent tea leaves is bioavailable for animals (Croyle et al. 1974). Therefore, the most efficient method of utilizing the protein present in spent tea would be the recovery of protein by chemical means to produce a concentrated form of protein, which would be more useful for animal feed formulation.

Perera et al. (2007) optimized conditions for preparing Leaf Protein Concentrate (LPC) from refuse tea. This procedure includes alkali extraction of protein, precipitation of protein with trichloroacetic acid and recovery by centrifugation. The purified LPC obtained from refuse tea contained $42.8 \%$ crude protein, $0.9 \%$ crude fiber, $8.1 \%$ polyphenol, $5.1 \%$ ash and $1.6 \%$ ether extract (Perera et al. 2007). This LPC prepared from refuse tea seems to be a promising source of protein for humans and /or animals. However, conventional protein isolation procedures are lengthy and expensive (Lawhon et al. 1977). Polyphenols form complexes with protein and tend to co-precipitate and also phenolic compounds in leaf protein concentrate decrease its digestibility and nutritive value (Pierpoint, 1983).

Membrane filtration techniques are now used for clarification of fruit juices, syrup, wine, honey, etc (Kawakatsu et al. 1995). Semi-permeable ultrafiltration and reverse osmosis systems have been used commercially for a number of years to profitably process cheese whey (Crocco, 1975; Anon, 1975). Tzeng et al. (1988) recovered protein isolate from rapeseed by membrane filtration techniques which contained about $90 \%$ protein and the protein obtained were free of glucosinolate, low in phytate and fiber, light in color and plain in taste.

The present study was conducted to screen membranes, to optimize the membrane filtration parameters such as operating temperature and pressure for the preparation of protein-rich feed from spent tea and to evaluate the nutritional value of feed prepared. 


\section{MATERIALS AND METHODS}

\section{Screening of Membranes for Preparation of Feed From Spent Tea}

Refuse tea, collected from St Coombs factory, Talawakelle, was ground and sieved (No:20 mesh). One $\mathrm{kg}$ of ground refuse tea was brewed with boiling water for 10 minutes (Refuse tea: Water ratio 1: 10) and extracted by pressing. The residue left after water extraction (spent tea) was mixed with 12 liters of $0.1 \mathrm{~N}$ $\mathrm{NaOH}$ for $1 \mathrm{~h}$ and the slurry was pressed and alkali extract was taken. The alkali extract was pre-filtered using a $10 \mu \mathrm{m}$ sieve.

Ten liters of pre-filtered alkali extract was taken and passed through four sheets (area of a sheet is $0.018 \mathrm{~m}^{2}$ ) of each of following membranes with molecular weight cut off point (MWC) of 250,000, $100,00040,000,30,000,20,000$ and $10,000 \mathrm{Da}$ maintaining the feed temperature at $40{ }^{\circ} \mathrm{C}$ and inlet and outlet pressures at 5.6 and 4.8 bars respectively, using a membrane filtration pilot plant (Model-L, GEA Filtration, USA). Flux rates of each membrane were recorded. Permeates were collected and analyzed for total polyphenol, caffeine and crude protein contents by using Folin-Ciocalteu colorimetric method (ISO, 2005), highperformance liquid chromatography method (ISO, 2005) and Kjeldahl method (AOAC, 1999) respectively. Percentage of caffeine nitrogen was estimated by multiplying the caffeine percentage by the factor of $0.2884(56 / 194.19)$ and the protein content was estimated using the following equation (Eq. 1).

$$
\begin{aligned}
\text { Protein } \%= & (\text { Total Nitrogen } \%- \\
& \text { Caffeine Nitrogen } \%) * 6.25
\end{aligned}
$$

(Eq. 1)

Data were statistically analyzed by performing Duncan's multiple range test using SAS statistical package.

\section{Optimization of Operating Parameters for Membrane Filtration}

An alkali extract was prepared as described above and passed through the membrane with MWC of 100,000 Da at outlet pressures of 3, 5 and 7 bars. Respective inlet pressures were 4.6, 7 and 10 bars. This was repeated at feed temperatures of 30, 40 and $50{ }^{\circ} \mathrm{C}$. Flux rates were recorded and permeates were collected and analyzed for total polyphenol, caffeine and crude protein contents using the methods described above.

\section{Determination of Nutritional Value of Feed}

Alkali extract (14 L) was taken from 1.25 $\mathrm{kg}$ of refuse tea as described above and flux characteristics of this extract through the membrane with MWC of 100,000 Da (10 sheets) at feed temperature of $30{ }^{\circ} \mathrm{C}$ and inlet and outlet pressures of 4.6 and 3 bars respectively, was obtained. The extract (13 L) was concentrated to about 4 $\mathrm{L}$ (concentrate-1) by passing through the same membrane. Two and half liters of the concentrate-1 was mixed with same 
volume of water and concentrated again to about $2 \mathrm{~L}$ as above (concentrate-2). Finally, $1 \mathrm{~L}$ of the concentrate- 2 was diluted with $3 \mathrm{~L}$ of water and concentrated to about $1.5 \mathrm{~L}$ (concentrate-3). Samples from alkali extract and each concentrate were freeze-dried. Freeze-dried samples of concentrate-1, concentrate-2 and concentrate-3 were designated as Feed-1 (F-1), Feed-2 (F-2) and Feed-3 (F-3) respectively. Refuse tea, spent tea and freeze-dried samples were analyzed for crude protein, total polyphenol and for caffeine contents using the methods mentioned above. Crude fiber contents of these samples were estimated by weighing the dried residues left after acid and alkali digestion (ISO 15598:1998). These samples were also analyzed for total ash content by incineration in a furnace at $525 \pm 25{ }^{\circ} \mathrm{C}$ (ISO 1575:1980). Waterinsoluble ash contents of the samples were determined by extracting the total ash with hot water, filtration through ash less filter paper, ignition and weighing (ISO 1576:1975) and acid insoluble ash contents were determined by treating the total ash with hydrochloric acid solution, filtration, ignition and weighing of the residue (ISO 1577: 1980). Ether extract (total fat) of the samples was determined by hydrolyzing the samples with hydrochloric acid solution and extracting with ether (AOAC,1999). Amino acid composition of samples was determined by the methods described by John et al. (2000) using automated online derivatization system coupled with high performance liquid chromatograph (Zorbax Eclipse-AAA column, fluorescence detector).

\section{RESULTS AND DISCUSSION}

\section{Screening of Membrane for Preparation of Feed}

Membrane screening was done based on percentages of constituents (polyphenol, caffeine and protein) retained by each membrane and flux of those membranes.

According to the objectives, the maximum amount of unwanted compounds (polyphenol and caffeine) should pass through the membrane while retaining the maximum amount of protein. The separation would be more economical at higher flux. According to Table 1, only the membrane with MWC of 10,000 Da retained significantly higher percentage of protein $(77.4 \%)$ as compared to other membranes. However, the highest percentages of polyphenol (72.9\%) and caffeine $(40.8 \%)$ were retained by this membrane and gave the least flux (36.5 $\mathrm{L} / \mathrm{m}^{2} / \mathrm{h}$ ). The membrane with MWC of $100,000 \mathrm{Da}$ retained significantly lesser percentage of polyphenol (60\%) as compared to the membrane with MWC of $10,000 \mathrm{Da}$. Further, the membrane with MWC of $100,000 \mathrm{Da}$ retained significantly lesser percentage of caffeine (33.8\%) and gave significantly higher flux $\left(49 \mathrm{~L} / \mathrm{m}^{2} / \mathrm{h}\right)$ as compared to the membranes with MWC of 10,000 and 20,000 Da. Percentages of protein retained by the membranes with MWC above 10,000 Da were not significantly different. Therefore, out of membranes tested, membrane with MWC of 100,000 is more suitable for the preparation of protein-rich feed. 


\section{Optimization of Operating Parameters}

Though the percentage of caffeine retained decreased and flux increased significantly the percentage of protein retained decreased significantly with the increasing temperature (Table 2). Therefore, considering the percentage of protein retention and energy requirement it would be more beneficial to undertake membrane filtration at $30{ }^{\circ} \mathrm{C}$.

Table 1. Separation characteristics and flux of each membrane

\begin{tabular}{clllll}
\hline \multirow{2}{*}{$\begin{array}{c}\text { Treatment } \\
\text { No: }\end{array}$} & $\begin{array}{l}\text { Membrane } \\
\text { (MWC) }\end{array}$ & \multicolumn{5}{c}{ Mean values of constituents retained (Percentages) } \\
\cline { 3 - 6 } & & & & & \\
\hline 1 & 10,000 & $72.9 \pm 6.6 \mathrm{a}$ & $40.8 \pm 2.7 \mathrm{a}$ & $77.4 \pm 5.3 \mathrm{a}$ & $36.5 \pm 4.9 \mathrm{c}$ \\
2 & 20,000 & $67.3 \pm 3.2 \mathrm{ba}$ & $39.1 \pm 2.0 \mathrm{ba}$ & $68.1 \pm 6.0 \mathrm{~b}$ & $44.7 \pm 2.2 \mathrm{~b}$ \\
3 & 30,000 & $62.8 \pm 6.6 \mathrm{~b}$ & $36.5 \pm 3.6 \mathrm{bc}$ & $65.3 \pm 3.9 \mathrm{~b}$ & $47.3 \pm 2.1 \mathrm{ba}$ \\
4 & 40,000 & $62.9 \pm 8.8 \mathrm{~b}$ & $33.4 \pm 4.0 \mathrm{c}$ & $66.5 \pm 5.1 \mathrm{~b}$ & $48.6 \pm 1.8 \mathrm{a}$ \\
5 & 100,000 & $60.0 \pm 5.0 \mathrm{~b}$ & $33.8 \pm 4.6 \mathrm{c}$ & $67.9 \pm 2.3 \mathrm{~b}$ & $49.0 \pm 1.6 \mathrm{a}$ \\
6 & 250,000 & $60.1 \pm 5.8 \mathrm{~b}$ & $35.7 \pm 2.7 \mathrm{bc}$ & $66.0 \pm 4.0 \mathrm{~b}$ & $47.0 \pm 1.3 \mathrm{ba}$ \\
\hline CV & & 9.7 & 9.2 & 6.7 & 5.7 \\
\hline
\end{tabular}

Values are mean \pm Standard Deviation (n=6), MWC - Molecular Weight Cut Off Point, $C V$ Coefficient of Variance, Mean values within a column followed by different letters are significantly different $(p \leq 0.05)$

Table 2. Effect of temperature on separation characteristics and flux of the membrane with MWC of 100,000 Da

\begin{tabular}{clllll}
\hline & & \multicolumn{3}{l}{ Mean values of constituents retained (percentages) } \\
\cline { 3 - 6 } $\begin{array}{l}\text { Treatment } \\
\text { No. }\end{array}$ & $\begin{array}{l}\text { Temperature } \\
\left({ }^{\mathbf{o}} \mathbf{C}\right)\end{array}$ & $\begin{array}{l}\text { Total } \\
\text { polyphenol }\end{array}$ & Caffeine & $\begin{array}{l}\text { True } \\
\text { protein }\end{array}$ & $\begin{array}{l}\text { Flux } \\
(\mathbf{L} / \mathbf{m} 2 / \mathbf{h})\end{array}$ \\
\hline 1 & 30 & $69.9 \pm 6.9 \mathrm{~b}$ & $32.1 \pm 4.7 \mathrm{a}$ & $90.7 \pm 2.9 \mathrm{a}$ & $74.2 \pm 8.7 \mathrm{c}$ \\
2 & 40 & $68.1 \pm 5.1 \mathrm{c}$ & $29.4 \pm 2.9 \mathrm{~b}$ & $82.6 \pm 3.9 \mathrm{~b}$ & $89.2 \pm 7.5 \mathrm{~b}$ \\
3 & 50 & $76.4 \pm 5.4 \mathrm{a}$ & $23.3 \pm 4.5 \mathrm{c}$ & $73.6 \pm 7.0 \mathrm{c}$ & $99.4 \pm 15.4 \mathrm{a}$ \\
\hline $\mathrm{CV}$ & & 2.8 & 12.5 & 5.8 & 1.4 \\
\hline
\end{tabular}

$\overline{\text { Values are mean } \pm \text { Standard Deviation }(n=3), M W C-\text { Molecular Weight Cut Off Point, } C V}$ Coefficient of Variance, Mean values within a column followed by different letters are significantly different $(p \leq 0.05)$. 
Though the flux increased with the increasing pressure, percentages of polyphenol and caffeine retained also increased and pressure did not significantly affect on percentage of protein retained (Table 3). Minimum percentages of unwanted compounds, polyphenol (64.7\%) and caffeine $(25.3 \%)$ were retained at the inlet and outlet pressures of 4.6 and 3 bars, respectively. Considering minimum retention of unwanted compound and energy requirement it would be suitable to undertake membrane separation at inlet and outlet pressures of 4.6 and 3 bars, respectively.

\section{Nutritional Value of Feed Concentrates}

Dried alkali extract contained $17.5 \%$ protein. However, it also contained a high level of anti-nutritive constituents polyphenol $(12.2 \%)$ and caffeine $(2.8 \%)$ (Table 4). Moreover, it also contained a high level of total ash (18.1\%). Feed-3 obtained by membrane concentration of alkali extract followed by two consecutive dia-filtration, contained high level of protein $(24.2 \%)$ and low level of polyphenol $(7 \%)$, caffeine $(0.9 \%)$ and total ash $(12.3 \%)$ as compared to those of alkali extract (Table 4). The high fiber content in animal feed indicates a rather low bioavailability of feed energy (Croyle et al. 1974). Feed-3 contained a very low level of crude fiber $(0.44 \%)$ which is advantageous as far as an animal feed is concerned. Some minerals are essential for optimum growth and performance of both human and animals because they play important roles as, structural components of connective tissues $(\mathrm{Ca})$, constituents of enzymes involved in metabolism ( $\mathrm{Zn}$ ), component of blood hemoglobin (Fe), enzyme activators ( $\mathrm{Mg}, \mathrm{Mn}, \mathrm{Cu})$ and osmotic pressure regulators $(\mathrm{Na}, \mathrm{K})$ (Corah, 1996; Potter and Hotchkiss, 1996; Ahmed et al. 2000; Hostetler et al. 2003; Cabrera et al. 2004; Rude et al. 2005). Out of the total ash content of Feed-3, more than $80 \%$ was water-soluble ash (Table 4 ).

Table 3. Effect of pressure on separation characteristics and flux of 100,000MWC membrane

\begin{tabular}{cllllll}
\hline $\begin{array}{l}\text { Treatment } \\
\text { No: }\end{array}$ & \multicolumn{2}{l}{ Pressure (bar) } & \multicolumn{2}{l}{ Mean values of constituents retained (percentages) } \\
\cline { 2 - 7 } & Inlet & Outlet & $\begin{array}{l}\text { Total } \\
\text { polyphenol }\end{array}$ & Caffeine & True protein & $\begin{array}{l}\text { Flux } \\
\left(\mathbf{L} / \mathbf{m}^{2} / \mathbf{h}\right)\end{array}$ \\
\hline 1 & 4.6 & 3 & $64.7 \pm 4.2 \mathrm{c}$ & $25.3 \pm 6.2 \mathrm{~b}$ & $83.2 \pm 5.7 \mathrm{a}$ & $75.2 \pm 8.6 \mathrm{c}$ \\
2 & 7 & 5 & $72.0 \pm 4.6 \mathrm{~b}$ & $28.9 \pm 4.6 \mathrm{a}$ & $81.8 \pm 9.6 \mathrm{a}$ & $87.7 \pm 9.8 \mathrm{~b}$ \\
3 & 10 & 7 & $77.7 \pm 3.8 \mathrm{a}$ & $30.7 \pm 4.4 \mathrm{a}$ & $82.0 \pm 10.0 \mathrm{a}$ & $99.8 \pm 14.8 \mathrm{a}$ \\
\hline CV & & & 2.8 & 12.5 & 5.8 & 1.4 \\
\hline
\end{tabular}

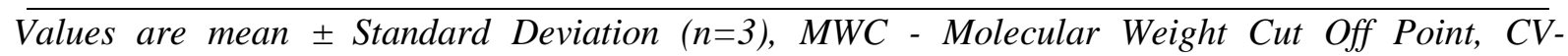
Coefficient of Variance, Mean values within a column followed by different letters are significantly different $(p \leq 0.05)$. 
Table 4. Proximate composition of refuse tea, spent tea and freeze dried samples of alkali extract and feed at different stages of purification

\begin{tabular}{lllllll}
\hline & \multicolumn{5}{c}{ Sample } \\
\cline { 2 - 7 } Constituent & $\begin{array}{l}\text { Refuse } \\
\text { tea }\end{array}$ & $\begin{array}{l}\text { Spent } \\
\text { tea }\end{array}$ & $\begin{array}{l}\text { Alkali } \\
\text { extract }\end{array}$ & F-1 & F-2 & F-3 \\
& $16.3 \pm 0.1$ & $16.1 \pm 0.1$ & $17.5 \pm 0.3$ & $22.4 \pm 0.7$ & $22.5 \pm 0.0$ & $24.2 \pm 1.2$ \\
Protein (\%) & $0.18 \pm 0.02$ & $0.40 \pm 0.04$ & $0.47 \pm 0.02$ & $0.41 \pm 0.11$ & $0.65 \pm 0.07$ & $0.39 \pm 0.39$ \\
Ether extract (\%) & $20.5 \pm 0.5$ & $25.4 \pm 0.4$ & $0.58 \pm 0.08$ & $0.31 \pm 0.04$ & $0.48 \pm 0.04$ & $0.44 \pm 0.05$ \\
Crude fiber (\%) & $5.3 \pm 0.1$ & $3.1 \pm 0.1$ & $18.1 \pm 0.1$ & $13.9 \pm 0.3$ & $13.9 \pm 0.9$ & $12.3 \pm 0.9$ \\
Total ash (\%) & $2.2 \pm 0.0$ & $2.0 \pm 0.1$ & $2.2 \pm 0.1$ & $2.1 \pm 0.2$ & $2.4 \pm 0.1$ & $2.2 \pm 0.1$ \\
WIS ash (\%) & $0.48 \pm 0.07$ & $0.33 \pm 0.10$ & $0.30 \pm 0.02$ & $0.35 \pm 0.02$ & $0.36 \pm 0.01$ & $0.33 \pm 0.02$ \\
AIS ash (\%) & $10.8 \pm 0.2$ & $7.3 \pm 0.5$ & $12.2 \pm 1.8$ & $10.2 \pm 0.9$ & $7.1 \pm 0.3$ & $7.0 \pm 0.9$ \\
TPP (\%) & $1.24 \pm 0.12$ & $0.71 \pm .01$ & $2.8 \pm 0.0$ & $1.9 \pm 0.013$ & $1.3 \pm 0.0$ & $0.9 \pm 0.002$ \\
Caffeine (\%) & & & $324 \pm 12$ & $246 \pm 14$ & $215 \pm 4$ & $196 \pm 9$ \\
TS $(g / K g$ of $R T)$ & & & & & &
\end{tabular}

Values are mean \pm Standard Deviation ( $n=3), F-1$ - Freeze dried concentrate -1, F-2- Freeze dried concentrate-2, F-3- Freeze dried concentrate-3, WIS-Water insoluble, AIS-Acid insoluble, TPP-Total polyphenol, TS- Total Solid, RT-Refuse Tea.

Calcium, Iodine, Iron, Magnesium,

Table 5. Amino acid composition of feed (F-3)

Phosphorus etc. are water-soluble minerals (Dietary Supplement Guide). Therefore, there can be high level of these minerals in Feed- 3 and it would be beneficial in animal feed formulation.

All essential amino acids except threonine were present in feed-3 (Table 5). Valine $(2107 \mathrm{mg} / 100 \mathrm{~g})$ was the most abundant amino acid present in feed-3. Furthermore, F-3 contained higher amount of cystine $(1964 \mathrm{mg} / 100 \mathrm{~g})$ as well. Tea as well as spent tea contain all essential amino acid (Jayasuriya et al. 1978; Liang et al. 2001). Therefore, the threonine may not be extracted into alkali solution or may have passed through the membrane.

\begin{tabular}{ll}
\hline Amino acid & Amount $\mathbf{( m g / 1 0 0 ~ g )}$ \\
\hline Aspartate & $136 \pm 7$ \\
Glutamate & $272 \pm 7$ \\
Serine & $194 \pm 6$ \\
Histidine & $35 \pm 3$ \\
Glycine & $515 \pm 7$ \\
Threonine & $\mathrm{ND}$ \\
Arginine & $286 \pm 4$ \\
Alanine & $199 \pm 4$ \\
Tyrosine & $84 \pm 4$ \\
Cystine & $1964 \pm 163$ \\
Valine & $2107 \pm 326$ \\
Methionine & $171 \pm 27$ \\
Phenilealanine & $77 \pm 2$ \\
Isoleucine & $66 \pm 2$ \\
Leucine & $195 \pm 5$ \\
Lysine & $46 \pm 1$ \\
Proline & ND \\
\hline Values are mean \pm Standard Deviation $(n=2)$, \\
ND: Not detected.
\end{tabular}




\section{CONCLUSION}

It can be concluded that membrane with MWC of 100,000 Da is suitable for the preparation of protein-rich feed from spent tea. Operating temperature of $30{ }^{\circ} \mathrm{C}$ and inlet and outlet pressure of 4.6 and 3 bars respectively are suitable for membrane filtration. Protein-rich feed with high nutritive value can be prepared by the membrane filtration technique.

\section{ACKNOWLEDGEMENT}

Authors thank the management of the Tea Research Institute of Sri Lanka for granting facilities to undertake this research and Mr. M.W. Silva for giving technical assistance to conduct the research.

\section{REFERENCES}

Ahmed, M.M.M., Siham, A.K. and Barri, M.E.S. (2000). Macro mineral profile in the plasma of nubian goats as affected by the physiological state. Small Ruminant Research, 38: 249254.

Ananthasubramaniam, C.R. and Menachery, M. (1977). Nutritive value of tea (Camellia sinensis, Linn) waste for cattle. Kerala J. Vet. Sci., 8(1): 3740.

Anon. (1975). Reverse osmosis saves cheese plant \$15,489/year. Food Engr., 47(9): 76.

AOAC. (1999). Official methods of analysis $\left(16^{\text {th }}\right.$ ed). Association of Official Analytical Chemist, Washington DC.

Balentine, D.A., Harbowy, M.E. and Graham, H.N. (1998). Tea: The plant and its manufacture; chemistry and consumption of the beverage. In G.A. Spiller (Editor), Caffeine, CRC Press LLC, New York, 35-72.

Cabrera, N.W.G., Coffey, K.P., Coblentz, W.K., Sarbrough, D.A., Turner, J.E., Kegley, E.B., Johnson, Z.B., Kellogg, D.W., Gunsaulis, J.L. and Daniels, M.B. (2004). In-situ solubility of selected macro minerals from common bermunda grass fertilized with different nitrogen rates and harvested on two dates. Anim. Feed Sci. Technol., 3(1-4): 203-221.

Corah, L. (1996). Trace mineral requirement of grazing cattle. Anim. Feed Sci. Technol., 59: 61-70.

Crocco, S.C. (1975). Ultrafiltration excels in whey protein recovery. Food Engr., 47(11): 59.

Croyle, R.D., Wilson, L.L. and Long, T.A. (1974). Potential of spent tea leaves for animal feeds and composting. Compost Sci., (March-April), 28-30.

Dietary-supplements-guide available from: http://www.dietary-supplementsguide.com/Health-Benefits-of-minerals (Accessed: 23 August 2014).

Harbowy, M.E. and Balentine, D.A. (1997). Tea chemistry a critical review. Plant Sci., 16: 415-480.

Hostetler, C.E., Kincaid, R.L. and Mirando, M.A. (2003). The role of essential trace elements in embryonic and foetal development in livestock. The Veterinary Journal, 166: 125-139.

John, W.H., Robert, D.R., Brian, A., Bidlingmeyer and Cliff, W. (2000). Rapid, accurate, sensitive and reproducible HPLC analysis of amino acids. Technical note. Agilent Technologies, USA.

ISO 1452-1. (2005). Determination of substances characteristics of green and black tea. Part 1: Determination of total polyphenols in tea-colorimetric method 
using folin-ciocalteu reagent. ISO Central Secretariat, International Organization for Standardization, Geneva, Switzerland.

ISO 14502-2. (2005). Determination of substances characteristics of green and black tea. Part 2: Content of catechins in green tea-Method using high performance liquid chromatography. ISO Central Secretariat, International Organization for Standardization, Geneva, Switzerland.

ISO 1575 1980. Tea-Determination of total ash. ISO Central Secretariat, International Organization for Standardization, Geneva, Switzerland

ISO 1576. (1975). Tea-Determination of water soluble ash and water insoluble ash. ISO Central Secretariat, International Organization for Standardization, Geneva, Switzerland.

ISO 1577. (1980). Tea-Determination of acid insoluble ash. ISO Central Secretariat, International Organization for Standardization, Geneva, Switzerland.

ISO 15598. (1998). Test method for determination of crude fibre content in tea. ISO Central Secretariat, International Organization for Standardization, Geneva, Switzerland.

Jayasuriya, M.C.N., Panditharatne, S. and Roberts, G. (1978). Spent tea leaf as a ruminant feed. Anim. Feed Sci. Technol., 3: 219-226.

Jayasuriya, M.C.N., Perdok, H.B., RosParker, H.M., Houtert, M.F.J. V. (1982). Effect of alkali - treated rice straw supplemented with spent tea leaf and thyroprotein on milk yield, milk composition and certain physiological parameters of dairy cows. Anim. Feed. Sci. Technol., 7: 201-216.

Kadirvel, R. (1980). The use of spent tea dust in a layer mash. Cheiron, 9(3): 135-137.
Kawakatsu, T., Kobayashi, T., Sano, Y. and Nakajima, M. (1995). Clarification of green tea extract by microfiltration and ultrafiltration. Biosci. Biotech. Biochem., 59(6): 1016-1020.

Lawhon, J.T., Mulsow, D., Cater, C.M. and Mattil, K.F. (1977). Production of protein isolates and concentrates from oilseed flour extracts using industrial ultrafiltration and reverse osmosis systems. J. Food Sci., 42:389-394.

Liang, Y., Ma, W., Lu, J, and Wu, Y. (2001). Comparison of chemical composition of Ilex latifolia Thumb and Camellia sinensis L. Food Chemistry, 75: 339-343.

Perera, G.A.A.R., Abeysinghe, I.S.B. and Jayaweera, C.D. (2007). Optimization of conditions for preparing leaf protein concentrate from refuse tea. J. Food Sci. Tecnol., 44(4): 413-416.

Pierpoint, W.S. (1983). Reaction of phenolic compounds with proteins, and their relevance to the production of leaf protein. In: L. Telek. and H.D. Graham (Editors), Leaf protein concentrates. AVI Publishing Company inc, Westport, Connecticut, 235-265.

Potter, N.N. and Hotchkiss, J.H. (1996). Food Science $\left(5^{\text {th }}\right.$ edition), CBS publishers and distributors, New Delhi, India, 608.

Rude, R.K., Gruber, H.E., Norton, H.J., Wei, L.Y., Frusto, A. and Kilburn, J. (2005). Dietary magnesium reduction to $25 \%$ of nutrient requirement disrupts bone and mineral metabolism in the rat. Bone 37(2): 211-219.

Tzeng, Y.M., Diosady, L.L. and Rubin, L.J. (1988). Preparation of rape seed protein isolate by sodium hexametaphosphate extraction, ultrafiltration, diafiltration and ionexchange. J. Food Sci., 53(5): 15371541. 
G.A.A. R. Perera et al.

Wickremasinghe, R.L. (1978). Monograph on tea production in Sri Lanka No: 07. Tea Research Institute of Sri Lanka, Sri Lanka. 